\title{
Discovery of okilactomycin and congeners from Streptomyces scabrisporus by antisense differential sensitivity assay targeting ribosomal protein S4
}

\author{
Chaowei Zhang ${ }^{1}$, John G Ondeyka ${ }^{1}$, Deborah L Zink ${ }^{1}$, Angela Basilio ${ }^{2}$, Francisca Vicente ${ }^{2}$, Oscar Salazar ${ }^{2}$, \\ Olga Genilloud ${ }^{2}$, Karen Dorso ${ }^{1}$, Mary Motyl ${ }^{1}$, Kevin Byrne ${ }^{1}$ and Sheo B Singh ${ }^{1}$
}

Protein synthesis inhibition is a highly successful target for developing clinically effective and safe antibiotics. There are several targets within the ribosomal machinery, and small ribosomal protein S4 (RPSD) is one of the newer targets. Screening of microbial extracts using antisense-sensitized rpsD Staphylococcus aureus strain led to isolation of okilactomycin and four new congeners from Streptomyces scabrisporus. The major compound, okilactomycin, was the most active, with a minimum detection concentration of 3-12 $\mu \mathrm{g} \mathrm{ml}^{-1}$ against antisense assay, and showed an MIC of 4-16 $\mu \mathrm{g} \mathrm{ml}^{-1}$ against Gram-positive bacteria, including $S$. aureus. The congeners were significantly less active in all assays, and all compounds showed a slight preferential inhibition of RNA synthesis over DNA and protein synthesis. Antisense technology, due to increased sensitivity, continues to yield new, even though weakly active, antibiotics.

The Journal of Antibiotics (2009) 62, 55-61; doi:10.1038/ja.2008.8; published online 9 January 2009

Keywords: antisense; natural products; RNA synthesis inhibitors; rpsD

\section{INTRODUCTION}

Bacterial resistance to antibiotics continues to increase and is reaching alarming levels for certain organisms, including methicillin-resistant Staphylococcus aureus and Pseudomonas aeruginosa, and remains a serious threat to human lives. ${ }^{1}$ The current clinically used antibiotics target fewer than 25 molecular targets, including a number of proteins of ribosomal targets in the protein synthesis machinery. Inhibition of protein synthesis is one of the most highly effective and proven antibacterial approaches. ${ }^{2,3}$ Protein synthesis is catalyzed by a ribosome that is comprised of two asymmetric macromolecular units, the large (50S) and small (30S) subunits. The small subunit is composed of $16 \mathrm{~S}$ rRNA and 21 r-proteins, S1-S21 (refs 4-6). Ribosomal proteins are known to help the ribosome to maintain its quaternary structure. Most of the clinically used drugs bind not only to rRNA but also to one or more ribosomal proteins, and the inhibition of protein synthesis is the composite result of disturbances due to both interactions. Alteration of rRNA binding to r-proteins inactivates protein synthesis. Therefore, selectively altering the conformation of a particular r-protein, or inhibiting the synthesis of an r-protein, would result in loss of function, and may lead to inhibition of the bacterial protein synthesis. Small ribosomal protein S4 (RPSD) is one of those proteins that seemed to be suitable targets for antibacterial discovery. It is encoded by the $r p s D$ gene in both Gram-positive and Gram-negative bacteria, is conserved across bacterial species and is essential for bacterial growth. ${ }^{7,8}$
A S. aureus-based antisense two-plate whole-cell differential sensitivity screening assay was designed earlier and developed by us for the discovery of new antibiotics. ${ }^{9,10}$ This assay was based on an antisense-sensitized $S$. aureus strain that targeted the $f a b F / H$ genes, leading to reduced expression and thus reduced production of FabF/H proteins. ${ }^{9,10}$ This assay led to the discovery of platensimycin and platencin, two novel and potent inhibitors of FabF and $\mathrm{FabF} / \mathrm{H}$ enzymes with in vivo antibiotic activities. ${ }^{11-14}$ A similar two-plate assay, with reduced expression of the $r p s D$ gene by antisense and hence reduced expression of the RPSD protein, was developed and used for screening of natural product extracts. This screening strategy led to the identification of lucensimycin A and $\mathrm{B}^{15}$ from a strain of Streptomyces lucensis MA7349, coniothyrione from a fungal strain of Coniothyrium cerealis MF7209 (ref. 16), pleosporone from an unidentified ascomycete ${ }^{17}$ and phaeosphenone from Phaeosphaeria sp. ${ }^{18}$ Continued screening of microbial extracts led to the discovery of a Streptomyces scabrisporus strain that showed good activity in the two-plate screening assay. The acetone extract of the fermentation broth produced by the strain was subjected to bioassay-guided fractionation, leading to the isolation of okilactomycin (1) and four new compounds, named okilactomycin A (2), B (3), C (4) and D (5) (Figure 1). The isolation, structure elucidation and biological characterization of these compounds are reported herein. 


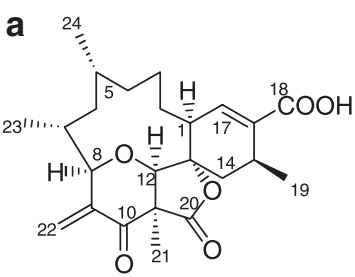

1: Okilactomycin

3: Okilactomycin B<smiles>CC=CC(=O)C1=C(O)[C@@]23OC(=O)C(C)=C[C@H]2CCC[C@@H](C)C[C@@H](C)C=C13</smiles>

5: Okilactomycin D

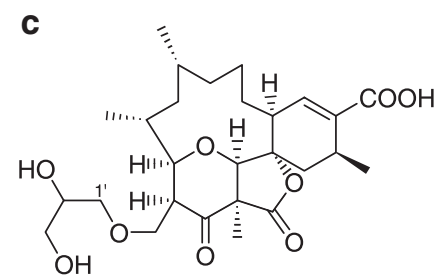

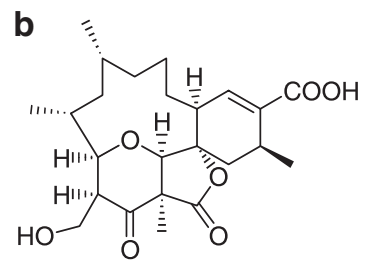

2: Okilactomycin A<smiles>CC=CC(=O)C1=C(O)C2(CCC[C@@H](C)CC(C)C)OC(=O)C(C(=O)O)=C[C@H]2O1</smiles>

4: Okilactomycin C
Figure 1 Chemical structures of okilactomycins. (a) Structure of okilactomycin, (b) structure of okilactomycin A, (c) structure of okilactomycin B, (d) structure of okilactomycin C and (e) structure of okilactomycin D.

\section{RESULTS AND DISCUSSION}

\section{Fermentation and isolation}

The producing organism was recovered from a soil sample collected in Costa Rica. The strain was characterized using morphological, chemotaxonomic and molecular identification (16S rDNA sequencing) methods, and was identified taxonomically as a new strain of $S$. scabrisporus. The strain was grown in millet, pharmamedia, glucose (MPG) liquid medium in a shake flask for 13 days.

The fermentation broth was extracted with equal volume of acetone, and the extract was concentrated to remove most of the acetone and chromatographed on Amberchrome polystyrene resin. The pooled biologically active fractions were chromatographed by reversed-phase HPLC to yield the known okilactomycin (1) $(9.3 \mathrm{mg}$, $\left.37.2 \mathrm{mgl}^{-1}\right)$, and novel okilactomycins A (2) $\left(5.7 \mathrm{mg}, 15.2 \mathrm{mgl}^{-1}\right), \mathrm{B}$ (3) $\left(0.8 \mathrm{mg}, 2.1 \mathrm{mgl}^{-1}\right), \mathrm{C}$ (4) $\left(4.2 \mathrm{mg}, 11.2 \mathrm{mgl}^{-1}\right)$ and $\mathrm{D}(5)$ (0.6 mg, $0.6 \mathrm{mg} \mathrm{l}^{-1}$ ).

\section{Structure elucidation}

Compound 1 exhibited a molecular weight of 416 atomic mass units (amu), with the molecular formula $\mathrm{C}_{24} \mathrm{H}_{32} \mathrm{O}_{6}$ (high resolution electrospray ionization fourier transform mass spectrometry (HRESIFTMS)), and was identified as okilactomycin by comparing with spectroscopic data $\left({ }^{1} \mathrm{H},{ }^{13} \mathrm{C}\right.$ NMR and HRMS $)$ and chiroptical properties $\left([\alpha]^{23}{ }_{D}=+30.0 c 0.5, \mathrm{MeOH}\right.$; Lit $\left.[\alpha]_{D}=+34\right)$. This was confirmed by full NMR shift assignment by $2 \mathrm{D}$ NMR. ${ }^{19}$ This structure was originally determined by X-ray crystallographic studies and was recently confirmed by asymmetric total synthesis of the unnatural opposite enantiomer. ${ }^{20}$ Okilactomycin exhibits modest antitumor activity and Gram-positive antibacterial activity. ${ }^{21}$
HRESIFTMS $\left(m / z \quad 435.2384[\mathrm{M}+\mathrm{H}]^{+}\right)$of okilactomycin A (2) suggested a molecular formula of $\mathrm{C}_{24} \mathrm{H}_{34} \mathrm{O}_{7}$, indicating 8 degrees of unsaturation. The molecular weight comparison of compound 2 with $\mathbf{1}$ suggested that $\mathbf{2}$ contained 18 additional atomic mass units. The UV spectrum showed absorption maxima at $\lambda_{\max } 212 \mathrm{~nm}$. The IR spectrum displayed absorption bands for three carbonyls, including a fivemembered lactone $\left(1778,1695\right.$ and $\left.1643 \mathrm{~cm}^{-1}\right)$ and an $\mathrm{OH}$ group $\left(3405 \mathrm{~cm}^{-1}\right)$. The ${ }^{13} \mathrm{C}$ NMR spectra (Table 1) showed 24 carbon resonances, which confirmed the molecular formula. DEPT experiments displayed 18 signals, including four methyl groups, six methylenes and eight methines, indicating the presence of two exchangeable protons. The presence of five $s p^{2}$ carbons, including one protonbearing carbon, two acid/ester/lactone-type carbonyls $\left(\delta_{\mathrm{C}} 168.2\right.$ and $\left.\delta_{\mathrm{C}} 172.0\right)$ and a ketone at $\delta 206.0$ further corroborated the okilactomycin skeleton. The key heteronuclear multiple bond correlations (HMBC) of $\mathrm{H}-8\left(\delta_{\mathrm{H}} 3.99\right)$ to $\mathrm{C}-12\left(\delta_{\mathrm{C}} 84.7\right) ; \mathrm{H}-12\left(\delta_{\mathrm{H}} 4.68\right)$ to $\mathrm{C}-1$ $\left(\delta_{\mathrm{C}} 42.8\right), \mathrm{C}-10\left(\delta_{\mathrm{C}} 206.0\right), \mathrm{C}-13\left(\delta_{\mathrm{C}} 85.4\right)$ and C-14 $\left(\delta_{\mathrm{C}} 34.6\right) ; \mathrm{H}-17$ $\left(\delta_{\mathrm{H}} 6.76\right)$ to $\mathrm{C}-13$; and $\mathrm{H}-21\left(\delta_{\mathrm{H}} 1.72\right)$ to $\mathrm{C}-10, \mathrm{C}-11\left(\delta_{\mathrm{C}} 54.5\right), \mathrm{C}-12$ and $\mathrm{C}-20\left(\delta_{\mathrm{C}} 172.0\right)$ confirmed the okilactomycin skeleton. The only difference between okilactomycin (1) and compound $\mathbf{2}$ is at C-9 and C-22. Compound 2 showed the presence of a hydroxy methylene, which replaced the exocyclic olefin of 1 . The assignment was confirmed by the presence of a pair of doublet of doublets at $\delta_{\mathrm{H}} 4.02$ and $\delta_{\mathrm{H}} 4.10\left(\mathrm{H}_{2}-22\right)$ in the ${ }^{1} \mathrm{H}$ NMR spectrum of $(2)$, which correlated to $\delta_{\mathrm{C}} 59.8$ and the absence of olefinic methylene resonances $\left(\delta_{\mathrm{H}} 5.75\right.$ and 6.37) of 1 and ${ }^{13} \mathrm{C}$ resonance at $\delta_{\mathrm{C}} 121.9$. COSY and TOCSY (TOtal Correlation SpectroscopY) correlations confirmed the presence of a methine at C-9 and its correlation to the hydroxy methylene group at $\mathrm{C}-22$. This was further confirmed by HMBC correlation of $\mathrm{H}-22$ to C10. The relative configuration was determined by measuring the vicinal coupling constants and NOESY correlations. The NOESY correlations of $\mathrm{H}-8$ to $\mathrm{H}-9, \mathrm{H}-12, \mathrm{H}-21$ and $\mathrm{H}-23$; $\mathrm{H}-12$ to $\mathrm{H}-1, \mathrm{H}-$ $2\left(\delta_{\mathrm{H}} 1.63\right)$ and $\mathrm{H}-21$; and $\mathrm{H}-9$ to $\mathrm{H}-21$ indicated that they were present on the same $\alpha$-face of the molecule. The NOESY correlations of H-7 to $\mathrm{H}-5$ and $\mathrm{H}-22$ indicated that they were present on the opposite face of the molecule. The NOESY correlations of pseudo-axial $\mathrm{H}-14 \alpha\left(\delta_{\mathrm{H}} 1.82\right)$ to $\mathrm{H}-3 \beta\left(\delta_{\mathrm{H}} 1.62\right)$ confirmed the configuration at the spiro center, $\mathrm{C}-13$. $\mathrm{H}-14 \alpha$ also showed a large coupling $(J=10.6 \mathrm{~Hz})$ with $\mathrm{H}-15$, indicating a diaxial coupling and thus placing the C-19 methyl group at the pseudo-equatorial orientation in the pseudo-chair conformation of the spiro-fused cyclohexene ring. On the basis of these data, structure $\mathbf{2}$ was assigned for okilactomycin A (2).

Okilactomycin B (3) was assigned a molecular formula of $\mathrm{C}_{27} \mathrm{H}_{40} \mathrm{O}_{9}$ by HRESIFTMS $\left(\mathrm{m} / z\right.$ 509.2750, $\left.[\mathrm{M}+\mathrm{H}]^{+}\right)$. The ${ }^{1} \mathrm{H}$ and ${ }^{13} \mathrm{C}$ NMR spectral data of compounds 2 and $\mathbf{3}$ were nearly identical. The molecular formula of $\mathbf{3}$ suggested the presence of an additional $\mathrm{C}_{3} \mathrm{H}_{6} \mathrm{O}_{2}$ unit. The ${ }^{13} \mathrm{C}$ NMR spectrum of 3 showed three extra oxygenated carbon signals, including two methylenes at $\delta_{\mathrm{C}} 64.7$ and $\delta_{\mathrm{C}} 73.5$, and one methine at $\delta_{\mathrm{C}} 71.3$, indicative of a glycerol unit, which was confirmed by an HMBC correlation of $\mathrm{H}-1^{\prime}$ to C-22. The negative ion ESIMS showed a major ion at $\mathrm{m} / \mathrm{z} 415$ (M-glycerol). Thus, the glycerol ether structure 3 was assigned for okilactomycin B (3).

The molecular formula $\mathrm{C}_{23} \mathrm{H}_{30} \mathrm{O}_{6}$ was assigned for okilactomycin $\mathrm{C}$ (4) by HRESIFTMS $\left(\mathrm{m} / \mathrm{z}\right.$ 403.2126, $\left.[\mathrm{M}+\mathrm{H}]^{+}\right)$analysis, indicating 9 degrees of unsaturation. Comparisons of ${ }^{1} \mathrm{H}$ and ${ }^{13} \mathrm{C}$ NMR spectra of compound $\mathbf{4}$ with those of 1-3 indicated that all of them belong to the same family. The UV spectrum showed absorption maxima at $\lambda_{\max }$ 210, 235 and $274 \mathrm{~nm}$, indicating a different conjugation pattern compared with the others in the series. The IR spectrum showed 
absorption bands characteristic of conjugated ketones $\left(v_{\max }=1700\right.$ and $1631 \mathrm{~cm}^{-1}$ ). The ${ }^{13} \mathrm{C}$ NMR spectrum (Table 2) displayed 23 carbon signals, including four methyl groups, five methylenes and six methines, indicating the presence of two exchangeable protons. The presence of nine $s p^{2}$ carbons, including two proton-bearing carbons, two downfield conjugated carbonyls $\left(\delta_{\mathrm{C}} 194.2\right.$ and 196.1) and two carboxy-type carbonyls $\left(\delta_{\mathrm{C}} 170.6,173.9\right)$, and the lack of the signals for oxygenated methines indicated that the pyranone ring was no longer present and was opened in 4. This supposition was supported by the presence of an olefinic methine $\delta_{\mathrm{H}} 6.21(\mathrm{H}-8)$ and an olefinic methyl group at $\delta_{\mathrm{H}} 1.84\left(\mathrm{H}_{3}-21\right)$. These were assigned to $\mathrm{C}-8$ and $\mathrm{C}-$ 21 , respectively, by HMBC correlations of $\mathrm{H}-8$ to C-6 $\left(\delta_{\mathrm{C}} 47.2\right)$, C-10 $\left(\delta_{\mathrm{C}} 196.1\right)$ and $\mathrm{C}-21\left(\delta_{\mathrm{C}} 12.2\right)$, and $\mathrm{H}_{3}-21$ to $\mathrm{C}-8, \mathrm{C}-9$ and C-10. The open pyranone $\alpha, \alpha$-diketo-lactone ring was confirmed by the key $\mathrm{HMBC}$ correlations of $\mathrm{H}-14 \alpha\left(\delta_{\mathrm{C}} 1.89\right)$ to $\mathrm{C}-1\left(\delta_{\mathrm{C}} 46.8\right), \mathrm{C}-12\left(\delta_{\mathrm{C}}\right.$ $194.2), \mathrm{C}-13\left(\delta_{\mathrm{C}} 85.8\right)$ and $\mathrm{C}-16\left(\delta_{\mathrm{C}} 134.8\right)$. The relative configuration of $\mathbf{4}$ was identical to that of $\mathbf{1 - 3}$ as determined by NOESY and vicinal $J$-values. As for compound $2, \mathrm{H}-14 \alpha\left(\delta_{\mathrm{H}} 1.76\right)$ showed a large coupling $(J=10.5 \mathrm{~Hz})$ with $\mathrm{H}-15$, whereas $\mathrm{H}-14 \beta\left(\delta_{\mathrm{H}} 1.89\right)$ showed a small coupling $(J=2.0 \mathrm{~Hz})$ with $\mathrm{H}-1\left(\delta_{\mathrm{H}} 2.24\right)$ through $\mathrm{W}$-type coupling, suggesting that $\mathrm{H}-15$ was axially oriented in a pseudo-chair conformation. These data helped to establish structure $\mathbf{4}$ for okilactomycin C (4)

Okilactomycin D was assigned a molecular formula of (5) $\mathrm{C}_{23} \mathrm{H}_{32} \mathrm{O}_{4}$ by HRESIFTMS $\left(\mathrm{m} / \mathrm{z} 373.2377[\mathrm{M}+\mathrm{H}]^{+}\right)$. The ${ }^{1} \mathrm{H}$ and ${ }^{13} \mathrm{C}$ NMR spectral data of compounds $\mathbf{4}$ and $\mathbf{5}$ were nearly identical. The absence of a carbonyl carbon at $\delta_{\mathrm{C}} 170.6$ and the presence of a methyl group at $\delta_{\mathrm{H}} 1.72\left(\delta_{\mathrm{C}} 21.2\right)$ indicated differences between the two compounds. The proton and carbon chemical shifts of C-17 shifted significantly upfield due to the absence of conjugation. The key HMBC correlations of $\mathrm{H}-17$ to $\mathrm{C}-18$; and $\mathrm{H}_{3}-18$ to $\mathrm{C}-15, \mathrm{C}-16$ and $\mathrm{C}-17$ confirmed structure 5 for okilactomycin D.

\section{Biological activities}

All five compounds were first evaluated in the $S$. aureus antisense $r p s D$-sensitized two-plate differential sensitivity assay. Okilactomycin showed the most potent activity in this assay and displayed a $20-\mathrm{mm}$ zone of clearance at $62 \mu \mathrm{g} \mathrm{ml}^{-1}$ on the antisense plate and $13 \mathrm{~mm}$ on the control plate. The zone of clearance was concentration dependent and was measured by twofold dilution. At 12.5, 6.25 and $3.13 \mu \mathrm{g} \mathrm{ml}^{-1}$, compound 1 showed 15, 13 and $11 \mathrm{~mm}$ zones of clearance on the antisense plate but no activity on the control plate. This indicated

Table $1{ }^{1} \mathrm{H}(500 \mathrm{MHz})$ and ${ }^{13} \mathrm{C}(125 \mathrm{MHz})$ NMR assignment of okilactomycins $A(2)$ and $\mathrm{B}(3)$ in acetone- $d_{6}$

\begin{tabular}{|c|c|c|c|c|c|c|}
\hline \multirow[b]{2}{*}{ No. } & \multicolumn{3}{|c|}{2} & \multicolumn{3}{|c|}{3} \\
\hline & $\delta_{H}(m u l t ., \mathrm{J}$ in $\mathrm{Hz})$ & $\delta_{C}$ & $H M B C(H \rightarrow C)$ & $\delta_{H}($ mult., J in $\mathrm{Hz})$ & $\delta_{C}$ & $H M B C(H \rightarrow C)$ \\
\hline 1 & 2.40, brdd, $6.1,10$ & 42.8 & $\mathrm{C}-2,3,13,16,17$ & 2.37, brdd, $6.5,10$ & 42.9 & \\
\hline \multirow[t]{2}{*}{2} & $1.39, \mathrm{dd}, 4.2,10$ & 33.0 & & 1.37, brdd, $3.6,10$ & 33.1 & \\
\hline & $1.63, \mathrm{~m}$ & & & $1.60, \mathrm{~m}$ & & \\
\hline \multirow[t]{2}{*}{3} & $1.62, \mathrm{~m}$ & 24.4 & & $1.62, \mathrm{~m}$ & 24.4 & \\
\hline & 1.79, brd, 13.9 & & & $1.76, \mathrm{~m}$ & & \\
\hline \multirow[t]{2}{*}{4} & 1.08, brd, 13.5 & 38.4 & & 1.04, brd, 13.5 & 38.4 & \\
\hline & 1.21, dddd, $2.0,4.7,11.8,13.7$ & & & 1.19, brdd, $10.8,13.5$ & & \\
\hline 5 & $1.95, \mathrm{~m}$ & 31.1 & & $1.96, \mathrm{~m}$ & 30.9 & \\
\hline \multirow[t]{2}{*}{6} & $0.96, \mathrm{dd}, 7.1,14.2$ & 45.8 & & $0.94, \mathrm{~m}$ & 45.9 & \\
\hline & $1.55, \mathrm{dd}, 9.2,14.2$ & & & $1.53, \mathrm{dd}, 9.6,14.4$ & & \\
\hline 7 & $2.10, \mathrm{ddq}, 9.0,10,6.6$ & 34.7 & & $2.02, \mathrm{~m}$ & 34.5 & \\
\hline 8 & $3.99, \mathrm{dd}, 4.1,10$ & 85.1 & $\mathrm{C}-6,7,12,22,23$ & $3.97, \mathrm{dd}, 5.1,10.3$ & 84.9 & C-6, 7, 12, 22 \\
\hline 9 & 2.95, ddd, $3.7,4.1,5.5$ & 52.7 & $\mathrm{C}-10,22$ & $3.03, \mathrm{dt}, 2.8,4.4$ & 50.7 & \\
\hline 10 & & 206.0 & & & 205.8 & \\
\hline 11 & & 54.5 & & & 54.4 & \\
\hline 12 & $4.68, \mathrm{~s}$ & 84.7 & $\mathrm{C}-1,10,11,13,14,21$ & $4.64, \mathrm{~s}$ & 84.9 & $\mathrm{C}-1,10,13,14,21$ \\
\hline 13 & & 85.4 & & & 85.6 & \\
\hline \multirow[t]{2}{*}{14} & 1.44, ddd, $2.0,6.4,14.9$ & 34.6 & & 1.42, ddd, $2.2,6.7,15$ & 34.7 & \\
\hline & $1.82, \mathrm{dd}, 10.6,14.9$ & & & $1.77, \mathrm{dd}, 10.6,15$ & & \\
\hline 15 & $2.58, \mathrm{ddq}, 1.6,10.5,6.8$ & 28.2 & & $2.58, \mathrm{ddq}, 1.8,10.7,6.9$ & 28.3 & \\
\hline 16 & & 134.5 & & & 134.6 & \\
\hline 17 & $6.76, \mathrm{dd}, 2.0,6.0$ & 140.1 & $\mathrm{C}-1,2,13,15,16,18$ & $6.72, \mathrm{dd}, 2.1,6.0$ & 140.1 & $\mathrm{C}-1,13,15,16,18$ \\
\hline 18 & & 168.2 & & & 168.2 & \\
\hline 19 & $1.09, \mathrm{~d}, 7.1$ & 20.4 & $\mathrm{C}-14,15,16$ & $1.11, \mathrm{~d}, 6.6$ & 20.5 & $\mathrm{C}-14,15,16$ \\
\hline 20 & & 172.0 & & & 172.1 & \\
\hline 21 & $1.72, \mathrm{~s}$ & 24.9 & C-10, 11, 12, 20 & $1.70, \mathrm{~s}$ & 24.8 & C-10, 11, 12, 20 \\
\hline \multirow[t]{2}{*}{22} & $4.02, \mathrm{dd}, 3.7,11.2$ & 59.8 & $\mathrm{C}-8,9,10$ & $3.79, \mathrm{dd}, 2.7,9.6$ & 68.5 & \\
\hline & $4.10, \mathrm{dd}, 5.5,11.1$ & & & $4.06, \mathrm{dd}, 5.1,10.0$ & & \\
\hline 23 & $0.97, \mathrm{~d}, 7.1$ & 19.0 & $\mathrm{C}-6,7,8$ & $0.95, \mathrm{~d}, 6.6$ & 19.2 & $\mathrm{C}-6,7,8$ \\
\hline 24 & $0.88, \mathrm{~d}, 7.1$ & 24.0 & $C-4,5,6$ & $0.89, \mathrm{~d}, 6.6$ & 23.9 & $\mathrm{C}-4,5,6$ \\
\hline $1^{\prime}$ & & & & $3.46, d, 5.7$ & 73.5 & $C-22,2^{\prime}, 3^{\prime}$ \\
\hline $2^{\prime}$ & & & & $3.77, \mathrm{~m}$ & 71.3 & \\
\hline \multirow[t]{2}{*}{$3^{\prime}$} & & & & $3.53, \mathrm{~m}$ & 64.7 & \\
\hline & & & & $3.64, \mathrm{dd}, 4.5,10.9$ & & \\
\hline
\end{tabular}


Table $2{ }^{1} \mathrm{H}(500 \mathrm{MHz})$ and ${ }^{13} \mathrm{C}(125 \mathrm{MHz})$ NMR assignment of okilactomycins $\mathrm{C}(4)$ and $\mathrm{D}(5)$ in $\mathrm{CD}_{3} \mathrm{OD}$

\begin{tabular}{|c|c|c|c|c|c|c|}
\hline \multirow[b]{2}{*}{ No. } & \multicolumn{3}{|c|}{4} & \multicolumn{3}{|c|}{5} \\
\hline & $\delta_{H}$ (mult., J in $\left.H z\right)$ & $\delta_{C}$ & $H M B C(H \rightarrow C)$ & $\delta_{H}(m u l t ., \mathrm{J}$ in $\mathrm{Hz})$ & $\delta_{C}$ & $H M B C(H \rightarrow C)$ \\
\hline 1 & 2.24, brdd, $5.6,7.9$ & 46.8 & & $2.02, \mathrm{~m}$ & 47.3 & $\mathrm{C}-2$ \\
\hline \multirow[t]{2}{*}{2} & $1.14, \mathrm{~m}$ & 28.9 & $C-1,3,4,13,17$ & $1.12, \mathrm{~m}$ & 30.0 & $\mathrm{C}-1,3,4,13,17$ \\
\hline & $2.39, \mathrm{~m}$ & & & $2.21, \mathrm{~m}$ & & \\
\hline \multirow[t]{2}{*}{3} & $1.39, \mathrm{~m}$ & 26.1 & & $1.37, \mathrm{~m}$ & 25.6 & \\
\hline & $1.75, \mathrm{~m}$ & & & $1.73, \mathrm{~m}$ & & \\
\hline \multirow[t]{2}{*}{4} & $1.14, \mathrm{~m}$ & 37.0 & & $1.18, \mathrm{~m}$ & 36.8 & \\
\hline & $1.37, \mathrm{~m}$ & & & $1.36, \mathrm{~m}$ & & \\
\hline 5 & $1.51, \mathrm{~m}$ & 29.4 & C-3, 4, 6, 7, 23 & $1.45, \mathrm{~m}$ & 29.8 & $C-3,4,6,7,23$ \\
\hline \multirow[t]{2}{*}{6} & $1.20, \mathrm{~m}$ & 47.2 & & $1.22, \mathrm{~m}$ & 46.4 & $C-4,5,7,8,23$ \\
\hline & $1.34, \mathrm{~m}$ & & & $1.38, \mathrm{~m}$ & & \\
\hline 7 & $2.59, \mathrm{~m}$ & 33.2 & & $2.64, \mathrm{~m}$ & 33.1 & \\
\hline 8 & $6.21, \mathrm{~d}, 7.3$ & 151.0 & C-6, 7, 10, 21 & $6.38, \mathrm{dd}, 1.2,7.5$ & 154.3 & $\mathrm{C}-6,7,9,10,21,22$ \\
\hline 9 & & 140.0 & & & 140.1 & \\
\hline 10 & & 196.1 & & & 194.3 & \\
\hline 11 & & 101.3 & & & 101.2 & \\
\hline 12 & & 194.2 & & & 187.3 & \\
\hline 13 & & 85.8 & & & 87.3 & \\
\hline \multirow[t]{2}{*}{14} & $1.76, \mathrm{dd}, 10.5,14.5$ & 35.1 & C- $1,12,13,15,16,22$ & $1.73, \mathrm{dd}, 10.4,14.2$ & 35.3 & $\mathrm{C}-1,12,13,15,16,19$ \\
\hline & 1.89, ddd, $2.0,6.0,14.5$ & & & 1.80, ddd, $1.6,5.9,13.8$ & & \\
\hline 15 & 2.77, ddh, $1.8,10.5,6.7$ & 28.7 & & $2.38, \mathrm{dq}, 10.7,6.7$ & 32.1 & \\
\hline 16 & & 134.8 & & & 136.9 & \\
\hline 17 & $6.94, \mathrm{dd}, 1.8,5.5$ & 140.6 & $\mathrm{C}-1,13,15,16,18$ & $5.57, \mathrm{td}, 1.5,5.0$ & 125.0 & $\mathrm{C}-1,13,15,18$ \\
\hline 18 & & 170.6 & & $1.72, \mathrm{~d}, 1.2$ & 21.2 & $\mathrm{C}-15,16,17$ \\
\hline 19 & $1.18, \mathrm{~d}, 6.8$ & 20.5 & C- $14,15,16$ & $1.10, \mathrm{~d}, 7.0$ & 19.4 & $\mathrm{C}-14,15,16$ \\
\hline 20 & & 173.9 & & & 172.1 & \\
\hline 21 & $1.84, \mathrm{~s}$ & 12.2 & $\mathrm{C}-8,9,10$ & $1.86, \mathrm{~d}, 1.1$ & 11.8 & C-8, 9, 10 \\
\hline 22 & $0.98, d, 6.8$ & 20.5 & C-6, 7, 8 & $1.01, \mathrm{~d}, 7.0$ & 20.2 & C-6, 7, 8 \\
\hline 23 & $0.88, d, 6.8$ & 21.0 & $C-4,5,6$ & $0.89, \mathrm{~d}, 6.8$ & 20.9 & $C-4,5,6$ \\
\hline
\end{tabular}

a minimum detection concentration (MDC) of $3-12.5 \mu \mathrm{g} \mathrm{ml} l^{-1}$. Okilactomycins A-D were less active than okilactomycin. Of these four, okilactomycin A (2) showed the best activity with an MDC of 31-62 $\mu \mathrm{g} \mathrm{ml}^{-1}$. Okilactomycins B (3), C (4) and D (5) showed MDC values of 250,250 and $500 \mu \mathrm{g} \mathrm{ml}^{-1}$, respectively.

The most potent compound okilactomycin (1) exhibited an MIC of $8-16 \mu \mathrm{g} \mathrm{ml}^{-1}$ against S. aureus (Table 3). Compound 1 inhibited growth of Streptococcus pneumoniae (MIC of $8-16 \mu \mathrm{g} \mathrm{m}^{-1}$ ), Enterococcus faecalis (MIC of $16 \mu \mathrm{g} \mathrm{m}^{-1}$ ) and Bacillus subtilis (MIC of $4-16 \mu \mathrm{g} \mathrm{ml}^{-1}$ ). MIC data observed in this study are consistent with that reported earlier. ${ }^{21}$ Compound $\mathbf{1}$ did not show activity against Gram-negative bacteria, but did inhibit growth of the Escherichia coli (envA/tolC) strain, which harbors mutated membrane and efflux pump, and showed an MIC of $64 \mu \mathrm{g} \mathrm{ml}^{-1}$. The other four compounds were significantly less active in this assay with only $\mathbf{5}$ showing a weak activity against $S$. pneumoniae and also E. coli. No clear conclusion about SAR could be drawn due to weak activity.

Mechanistically, compounds 1, 2 and 4 showed preferential inhibition of RNA synthesis compared with DNA and protein synthesis (Figure 2a). These data are similar to the data observed for two other RPSD active compounds, pleosporone and phaeosphenone, identified by this assay. The other two compounds ( 3 and 5 ) showed $<50 \%$ inhibition at $100 \mu \mathrm{g} \mathrm{ml}^{-1}$ (data not shown). This phenomenon requires further study to determine why RPSD-selective compounds in the antisense assay tend to selectively inhibit RNA synthesis rather than protein synthesis.
In conclusion, antisense screening method continue to aid the discovery of novel antibiotics, even though with weak activity, as illustrated by the discovery of okilactomycin and its new congeners, okilactomycins A-D (2-5). The most abundant compound 1 remains the most active compounds in this family.

\section{EXPERIMENTAL PROCEDURE}

\section{General experimental procedures}

An Agilent HP1100 was used for analytical HPLC. Optical rotations were measured on a Perkin-Elmer 241 (Waltham, MA, USA) Polarimeter. UV spectra were recorded in $\mathrm{MeOH}$ on a Beckman (Fullerton, CA, USA) DU-70 Spectrophotometer. IR spectra were recorded on a Perkin-Elmer Spectrum One spectrometer. High resolution electrospray inonization mass spectrum (HRESIMS) were obtained on a Thermo Quest (Boston, MA, USA) FTMS spectrometer using electrospray ionization. The NMR spectra were recorded on a Varian (Palo Alto, CA, USA) INOVA 500 FT-NMR spectrometer at $500 \mathrm{MHz}$ for ${ }^{1} \mathrm{H}$ and $125 \mathrm{MHz}$ for ${ }^{13} \mathrm{C}$ in acetone- $d_{6}\left(\delta_{\mathrm{H}} 2.05, \delta_{\mathrm{C}} 29.92\right)$ and $\mathrm{CD}_{3} \mathrm{OD}\left(\delta_{\mathrm{H}} 3.31, \delta_{\mathrm{C}} 49.15\right)$.

\section{Microbial isolation conditions}

The strain F-117,187 was isolated from soil collected in Costa Rica, at the INBio Biodiversity Garden, from a coffee tree plantation area. This soil was air dried and suspended in sterile water. The soil suspension was serially diluted, plated on selective isolation media and incubated at $28^{\circ} \mathrm{C}$ for at least 6 weeks. The strain was isolated from an NZ-amine-based agar medium containing nalidixic acid $\left(20 \mu \mathrm{g} \mathrm{ml}^{-1}\right)$. The colony was purified on Yeast Extract Malt Extract Glucose medium (ISP2) and preserved as frozen agar plugs in 10\% glycerol. 
Table 3 Antibacterial activities (MIC, $\mu \mathrm{g} \mathrm{ml}^{-1}$ ) of okilactomycins (1-5)

\begin{tabular}{|c|c|c|c|c|c|c|c|}
\hline Strains ${ }^{\mathrm{b}}$ & Phenotype & Strain no. & $1^{\mathrm{c}}$ & $2^{c}$ & $3^{c}$ & $4 a^{c}$ & $4 b^{c}$ \\
\hline Staphylococcus aureus & meth $^{\mathrm{S}}$ & ATCC 29213 & 8 & $>64$ & $>64$ & $>64$ & $>64$ \\
\hline S. aureus & meth $^{S}$ & MB2865 & $16(8)$ & $>64$ & $>64$ & $>64$ & $>64$ \\
\hline S. aureus (+50\% human serum) & meth $^{S}$ & MB2865 & $>64$ & $>64$ & $>64$ & $>64$ & $>64$ \\
\hline Streptococcus pneumoniae ${ }^{\mathrm{d}}$ & pen $^{\mathrm{S}}$, quin ${ }^{\mathrm{s}}, \mathrm{mac}^{\mathrm{s}}$ & CL2883 & $16(8)$ & $>64$ & $>64$ & $>64$ & $>64(64)$ \\
\hline S. pneumoniae $\mathrm{e}^{\mathrm{e}}$ & pen $^{\mathrm{S}}$, quins ${ }^{\mathrm{S}}, \mathrm{mac}^{\mathrm{S}}$ & CL2883 & NT & $>64$ & $>64$ & $>64$ & $>64(32)$ \\
\hline Enterococcus faecalis & $\operatorname{van}^{\mathrm{S}}, \operatorname{mac}^{\mathrm{R}}$ & CL8516 & 16 & $>64$ & $>64$ & $>64$ & $>64$ \\
\hline Bacillus subtilis & Wt & MB964 & $16(4)$ & $>64$ & $>64$ & $>64$ & $>64$ \\
\hline Haemophilus influenzae & $\mathrm{Amp}^{\mathrm{S}}$, quin $\mathrm{S}, \mathrm{mac}^{\mathrm{S}}$ & MB4572 & $>64$ & $>64$ & $>64$ & $>64$ & $>64$ \\
\hline Escherichia coli & Wt & MB2884 & $>64$ & $>64$ & $>64$ & $>64$ & $>64(32)$ \\
\hline E. coli envA/tolC & Wt & MB5746 & 64 & $>64$ & $>64$ & $>64$ & $>64$ \\
\hline Candida albicans & Wt & MY1055 & $>64$ & $>64$ & $>64$ & $>64$ & $>64$ \\
\hline
\end{tabular}

Abbreviations: CAMHB, cation-adjusted Mueller-Hinton broth; MIC $_{80}$, MIC that inhibits $80 \%$ growth; NCCLS, National Committee for Clinical laboratory Standards.

${ }^{\mathrm{a}} \mathrm{MIC}$, the numbers in parentheses show the concentration of compound that inhibit $80 \%$ of cell growth.

${ }^{b}$ All strains were tested in CAMHB medium, unless mentioned otherwise, under the NCCLS guidelines.

${ }^{\mathrm{C}}$ The data in parentheses are $\mathrm{MIC}_{80}$.

dCAMHB $+2.5 \%$ lysed horse blood medium.

elsosensitest medium.

\section{Characterization of the $S$. scabrisporus strain}

Sporulating characters were observed upon growth of the strain on different selective media after 21 days incubation at $28^{\circ} \mathrm{C}$. The strain grows abundantly with extensive development of a gray to grayish brown aerial mycelium on media ISP2, ISP3, ISP5 and ISP7. It exhibited sparse growth and poor aerial development on medium ISP4. Microscopically, the strain produced long chains of spores as open coils or as loops formed at the end of the aerial hyphae. Good sporulation was observed on media ISP2, ISP3, ISP4 and ISP7 but no spore chains were formed on ISP5. This macro- and micromorphology are characteristic of members of the family Streptomycetaceae. Whole-cell major fatty acids were branched components iso- $\mathrm{C}_{16: 0}(29 \%)$, iso- $\mathrm{C}_{16: 1} \mathrm{H}(10 \%)$, unsaturated components $\mathrm{C}_{16: 1} \omega 7 \mathrm{c}(15 \%)$ and anteiso- $\mathrm{C}_{15: 0}(3.9 \%)$. The strain is characterized by good growth on glucose and rhamnose as the sole carbon source and exhibits limited growth on fructose, xylose, raffinose and inositol. No growth was observed on arabinose, cellulose, saccharose or mannitol.

\section{$16 S$ rDNA sequencing and phylogenetic analysis}

Total genomic DNA from the producing strain was isolated and purified using the MasterPure Gram-Positive DNA Purification Kit (Epicentre Biotechnologies, Madison, WI, USA). PCR primers $\mathrm{fD} 1$ and $\mathrm{rP}^{22}$ were used for amplifying the $16 \mathrm{~S}$ rRNA genes of the strain. The $1500 \mathrm{bp}$ PCR products were purified and used as a template in sequencing reactions using the primers $\mathrm{fD} 1$ and $\mathrm{rP} 2,{ }^{22}$ and $1100 \mathrm{R}$ and $926 \mathrm{~F}^{23}$ Amplified DNA fragments were sequenced using the ABI PRISMdye Terminator Cycle sequencing Kit and fragments were resolved using the ABI3130 genetic analyzer (Applied Biosystems, Foster City, CA, USA). Partial sequences were assembled using the contig editor component of GeneStudio Professional sequence analysis software (GeneStudio Inc., Suwanee, GA, USA). Almost complete 16S rDNA sequence was aligned with representative sequences of Streptomyces and related species as identified with BLAST searches. The phylogenetic analysis, based on the Neighbor-Joining method using matrix pairwise comparisons of sequences corrected with Jukes and Cantor algorithm, ${ }^{24,25}$ shows that the strain is closely related to the strain type S. scabrisporus NBRC $100760^{\mathrm{T}}$. The strains share $100 \%$ sequence identity and this relatedness is well supported in the analysis by the bootstrap value (100\%). All data suggest that strain F-117,187 can be identified as a new member of the species S. scabrisporus.

\section{Production conditions}

A seed culture of the strain was prepared by inoculation from a frozen vial containing agar plugs in a 50-ml Environmental Protection Agency (EPA) tube containing $10 \mathrm{ml}$ of seed medium (in $\mathrm{gl}^{-1}$ : soluble starch 20.0, dextrose 10.0, NZ amine type E 5.0, Difco Beef extract 3.0, Difco Bacto Peptone 5.0, Difco yeast extract 5.0 and $\mathrm{CaCO}_{3}$ 1.0). After 3 days of incubation at $28^{\circ} \mathrm{C}, 0.5 \mathrm{ml}$ of the inoculum was transferred to $50 \mathrm{ml}$ EPA tubes containing $10 \mathrm{ml}$ of production medium MPG (in $\mathrm{gl}^{-1}$ : glucose 10.0, ground millet 20.0, Pharmamedia 20.0 and MOPS 20.0), and the cultures were incubated at $28^{\circ} \mathrm{C}$ with 220 r.p.m. agitation and $70 \%$ humidity for 13 days. Production in flasks was obtained transferring $2.5 \mathrm{ml}$ of the inoculum from EPA tube to a $250-\mathrm{ml} \mathrm{flask}$ containing $50 \mathrm{ml}$ of the same production medium, and the culture was incubated at $28^{\circ} \mathrm{C}$ for 13 days in a rotary shaker at 220 r.p.m. and $70 \%$ humidity.

\section{Extraction and isolation}

A total of 40 flasks were harvested, pooled $(\sim 11)$ and extracted with 11 acetone by shaking on a platform shaker for $60 \mathrm{~min}$. The acetone extract was concentrated under reduced pressure to remove most of the acetone leaving behind mostly aqueous solution $(\sim 11)$, which was fractionated on an Amberchrome column, and eluted with a 100-min linear gradient of aqueous $\mathrm{MeOH}$ at a flow rate of $10 \mathrm{ml} \mathrm{min}^{-1}$. These fractions were tested for their biological activity in the antisense $r p s D$ two-plate assay. The fractions eluted with 52, 64, 78 and $90 \%$ aqueous $\mathrm{MeOH}$ possessed all of the biological activities.

A $25 \%$ aliquot of the Amberchrome fractions eluted with $78 \%$ aqueous $\mathrm{MeOH}$ was chromatographed by reversed-phase HPLC using an Atlantis $\mathrm{C}_{18}$ $(10 \times 250 \mathrm{~mm})$ column that was eluted with a 40 -min gradient of $20-95 \%$ aqueous $\mathrm{CH}_{3} \mathrm{CN}$ containing $0.1 \%$ TFA at a flow rate of $5 \mathrm{mlmin}^{-1}$. The fraction eluting at $28 \mathrm{~min}$ showed activity and was lyophilized to yield $9.3 \mathrm{mg}$ $\left(37.2 \mathrm{mg}^{-1}\right)$ of okilactomycin (1) as an amorphous powder.

A similar $25 \%$ aliquot of the Amberchrome fraction eluted with $64 \%$ aqueous $\mathrm{MeOH}$ was fractionated by reversed-phase HPLC using a Zorbax $\mathrm{C}_{8}$ $(21.2 \times 250 \mathrm{~mm})$ column that was eluted with a 40 -min gradient of $40-50 \%$ aqueous $\mathrm{CH}_{3} \mathrm{CN}$ containing $0.1 \%$ TFA at a flow rate of $10 \mathrm{ml} \mathrm{min}^{-1}$. Lyophilization of the active fractions eluting at 20 and $33 \mathrm{~min}$ yielded $0.8 \mathrm{mg}$ $\left(2.1 \mathrm{mgl}^{-1}\right)$ and $5.7 \mathrm{mg}\left(15.2 \mathrm{mgl}^{-1}\right)$ of okilactomycins B (3) and A (2), respectively, as colorless gums.

Similarly, 25\% aliquot of the Amberchrome fraction eluted at 52\% aqueous $\mathrm{MeOH}$ was further chromatographed on Zorbax $\mathrm{C}_{8}(21.2 \times 250 \mathrm{~mm})$ column that was eluted with a 40 -min gradient of $10-55 \%$ aqueous $\mathrm{CH}_{3} \mathrm{CN}$ containing $0.1 \%$ TFA at a flow rate of $10 \mathrm{ml} \mathrm{min}^{-1}$. Fractions eluting at $38 \mathrm{~min}$ showed activity and was lyophilized to furnish $4.2 \mathrm{mg}\left(11.2 \mathrm{mgl}^{-1}\right)$ of okilactomycin C (4) as a colorless gum.

Reversed-phase HPLC of the Amberchrome fraction eluted with $90 \%$ aqueous $\mathrm{MeOH}$ using Zorbax $\mathrm{C}_{8}(21.2 \times 250 \mathrm{~mm})$ column and eluted for 40 min with $45 \%$ aqueous $\mathrm{CH}_{3} \mathrm{CN}$ containing $0.1 \%$ TFA followed by a $10-$ min gradient of $45-95 \%$ aqueous $\mathrm{CH}_{3} \mathrm{CN}$ at a flow rate of $10 \mathrm{ml} \mathrm{min}^{-1}$, and lyophilization of the active fraction eluting at 69 min yielded $0.6 \mathrm{mg}$ $\left(0.6 \mathrm{mgl}^{-1}\right)$ of okilactomycin D (5) as a colorless gum.

Okilactomycin A (2): $[\alpha]^{23}{ }_{\mathrm{D}}-20$ (ca. 0.1, $\left.\mathrm{CH}_{3} \mathrm{OH}\right), \mathrm{UV}\left(\mathrm{CH}_{3} \mathrm{OH}\right) \lambda_{\max }$ $212(\varepsilon 10234) \mathrm{nm}$; IR (ZnSe) $v_{\max } 3405,2952,1778,1694,1643,1457,1385$, 

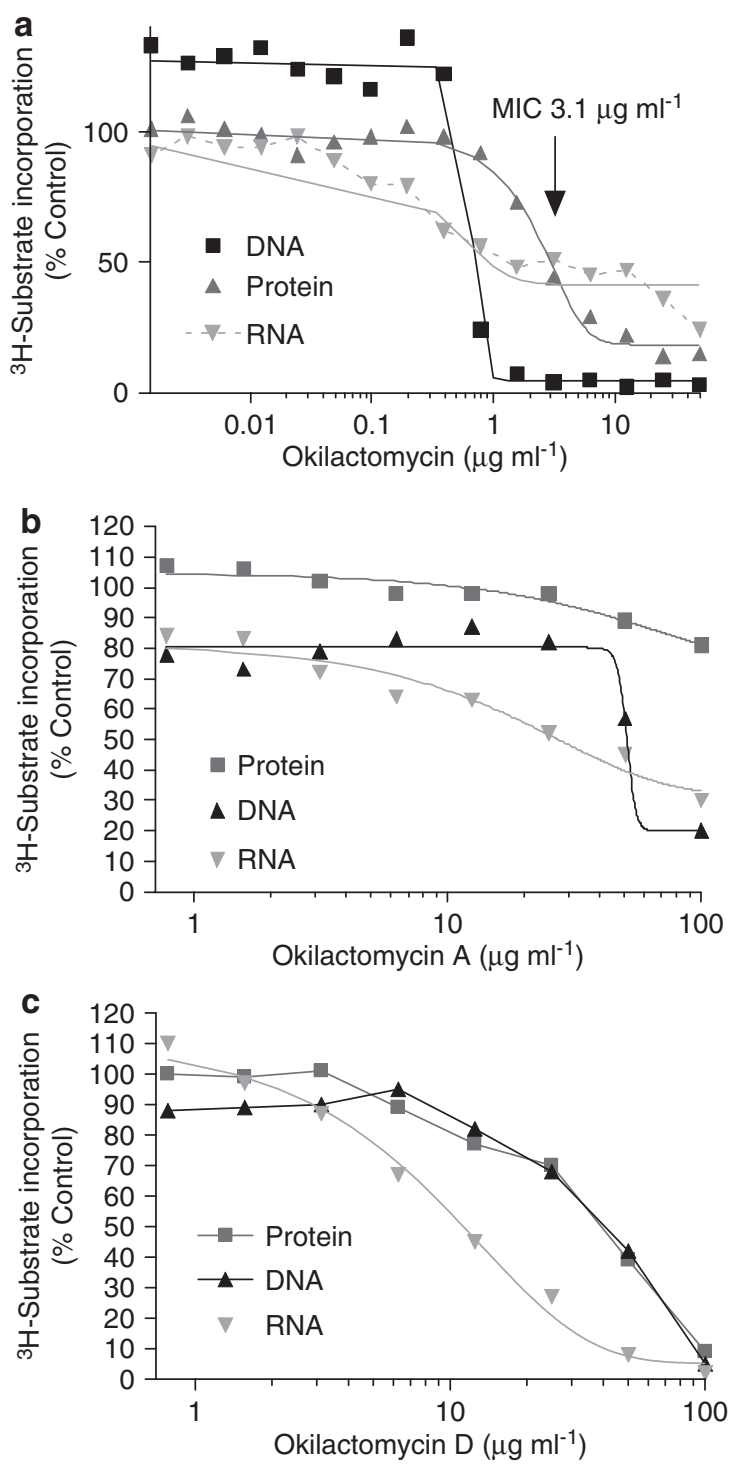

Figure 2 Macromolecular synthesis inhibition by okilactomycins (1, 2, 4). (a) Inhibition by okilactomycin (1), (b) inhibition by okilactomycin A (2) and (c) inhibition by okilactomycin D (4). Okilactomycins B and C showed $<50 \%$ inhibition of DNA, protein and RNA at $100 \mu \mathrm{g} \mathrm{ml}^{-1}$, therefore the data are not shown.

$1261,1233,1189,1138,1113,1068,1024,982,965,801,776$ and $723 \mathrm{~cm}^{-1}$; ${ }^{1} \mathrm{H}$ and ${ }^{13} \mathrm{C}$ NMR data, see Table 1; HRESI-FTMS $\mathrm{m} / \mathrm{z} 435.23839$ (calcd for $\left.\mathrm{C}_{24} \mathrm{H}_{34} \mathrm{O}_{7}+\mathrm{H}: 435.23826\right)$.

Okilactomycin B (3): $[\alpha]^{23}{ }_{\mathrm{D}}-20\left(\right.$ ca. $\left.0.1, \mathrm{CH}_{3} \mathrm{OH}\right)$; UV $\left(\mathrm{CH}_{3} \mathrm{OH}\right) \lambda_{\max }$ 212( $\varepsilon$ 6147) nm; IR (ZnSe) $v_{\max } 3419,2952,1779,1700,1642,1456,1261$, 1187, 1138, 1112, 1079, 1039, 1004, 962 and $687 \mathrm{~cm}^{-1} ;{ }^{1} \mathrm{H}$ and ${ }^{13} \mathrm{C}$ NMR data, see Table 1; HRESI-FTMS $m / z 509.27497$ (calcd for $\mathrm{C}_{27} \mathrm{H}_{40} \mathrm{O}_{9}+\mathrm{H}$ : 509.27503).

Okilactomycin C (4): $[\alpha]^{23}{ }_{\mathrm{D}}-30$ (ca. 0.1, $\left.\mathrm{CH}_{3} \mathrm{OH}\right) ; \mathrm{UV}\left(\mathrm{CH}_{3} \mathrm{OH}\right) \lambda_{\max }$ $210(\varepsilon 11328) 235\left(\varepsilon\right.$ 8281) 274( $\varepsilon$ 5797) nm; IR (ZnSe) $v_{\max } 2952,2927,1700$, 1631, 1454, 1258, 1134, 1025 and $988 \mathrm{~cm}^{-1} ;{ }^{1} \mathrm{H}$ and ${ }^{13} \mathrm{C}$ NMR data, see Table 2; HRESI-FTMS $m / z 403.2126$ (calcd for $\mathrm{C}_{23} \mathrm{H}_{30} \mathrm{O}_{6}+\mathrm{H}: 403.2120$ ).

Okilactomycin D (5): $[\alpha]^{23}{ }_{\mathrm{D}}-50\left(\right.$ ca. 0.1, $\left.\mathrm{CH}_{3} \mathrm{OH}\right) ; \mathrm{UV}\left(\mathrm{CH}_{3} \mathrm{OH}\right) \lambda_{\max }$ 204(ع 9940) 236( $\varepsilon$ 8824) 270( $\varepsilon$ 8295) nm; IR (ZnSe) $v_{\max } 3421,2928,2868$, $1688,1621,1594,1456,1377,1205,1136,1003$ and $968 \mathrm{~cm}^{-1}$; ${ }^{1} \mathrm{H}$ and ${ }^{13} \mathrm{C}$ NMR data, see Table 2; HRESI-FTMS $m / z 373.2377$ (calcd for $\mathrm{C}_{23} \mathrm{H}_{32} \mathrm{O}_{4}+\mathrm{H}$ : 373.2378)

\section{Two-plate differential sensitivity RPSD assay}

S. aureus cells (RN450) carrying either plasmid S1-782B bearing antisense to RPSD ( $r p s D$ AS-RNA strain) or empty vector (control strain) were inoculated from a frozen vial source into a $13-\mathrm{mm}$ disposable tissue culture tube containing $3 \mathrm{ml}$ of Miller's LB Broth (Invitrogen, Carlsbad, CA, USA) and $34 \mu \mathrm{g} \mathrm{ml}^{-1}$ of chloramphenicol. Tubes were incubated at $37^{\circ} \mathrm{C}$ with shaking at 220 r.p.m. for $18-20 \mathrm{~h}$ and kept at room temperature until use. Each culture was diluted (1:1000) to a final optical density at $600 \mathrm{~nm}\left(\mathrm{OD}_{600}\right)$ of 0.003 absorption unit (AU) into a flask containing Miller's LB broth medium supplemented with $1.2 \%$ Select agar (Invitrogen, autoclaved and cooled to $\left.48^{\circ} \mathrm{C}\right), 0.2 \%$ glucose, $15 \mu \mathrm{g} \mathrm{ml}^{-1}$ chloramphenicol and $12 \mathrm{~mm}$ of xylose (added for the antisense strain only). Two-assay plates, one seeded with the $r p s \mathrm{D}$ AS-RNA strain and the second with the control strain, were prepared by pouring $100 \mathrm{ml}$ of each of the above mixtures into a $20 \times 20 \mathrm{~cm}$ (NUNC) assay plate. Well-caster templates were placed into the agar, which was allowed to solidify at room temperature for $30 \mathrm{~min}$. Then, $20 \mu \mathrm{l}$ of test samples were added to the wells and the plates incubated at $37^{\circ} \mathrm{C}$ for $18 \mathrm{~h}$ and zones of inhibition measured. MDC values were determined by two-fold serial dilution.

\section{Antibiotic assay (MIC)}

MIC against each of the strains was determined using National Committee for Clinical Laboratory Standards (NCCLS)—now called National Laboratory Standard Institute (NLSI) - guidelines as described earlier. ${ }^{26}$ Cells were inoculated at $10^{5}$ colony-forming units per milliliter followed by incubation at $37^{\circ} \mathrm{C}$ with a twofold serial dilution of compounds in the growth medium for $20 \mathrm{~h}$. MIC is defined as the lowest concentration of an antibiotic inhibiting visible growth.

\section{Macromolecular synthesis inhibition}

The assay was performed as described earlier. ${ }^{11,27}$ Briefly, mid-log $\left(\mathrm{OD}_{600}=0.5-\right.$ $0.6, \mathrm{AU}) \mathrm{S}$. aureus growth was incubated at an increasing concentration of each inhibitor at $37^{\circ} \mathrm{C}$ for $20 \mathrm{~min}$ with $1 \mu \mathrm{Ci} \mathrm{ml}^{-1} 6-\left[{ }^{3} \mathrm{H}\right]$-thymidine, $1 \mu \mathrm{Ci} \mathrm{ml}^{-1}$ 5,6- $\left[{ }^{3} \mathrm{H}\right]$ uracil or $5 \mu \mathrm{Ciml}^{-1} 4,5-\left[{ }^{3} \mathrm{H}\right]$ leucine to measure DNA, RNA and protein synthesis, respectively. The reaction was stopped by the addition of $10 \%$ trichloroacetic acid and the cells were harvested using a glass fiber filter (Perkin-Elmer Life Sciences, 1205-401). The filter was dried and counted with scintillation fluid.

1 Klevens, R. M. et al. Invasive methicillin-resistant Staphylococcus aureus infections in the United States. J. Am. Med. Assoc. 298, 1763-1771 (2007).

2 Poehlsgaard, J. \& Douthwaite, S. The bacterial ribosome as a target for antibiotics. Nat. Rev. Microbiol. 3, 870-881 (2005).

3 Singh, S. B. \& Barrett, J. F. Empirical antibacterial drug discovery-foundation in natural products. Biochem. Pharmacol. 71, 1006-1015 (2006).

4 Ramakrishnan, V. Ribosome structure and the mechanism of translation. Cell 108, 557-572 (2002)

5 Culver, G. M. Assembly of the 30 S ribosomal subunit. Biopolymers 68, 234-249 (2003).

6 Ogle, J. M., Carter, A. P. \& Ramakrishnan, V. Insights into the decoding mechanism from recent ribosome structures. Trends Biochem. Sci. 28, 259-266 (2003).

7 Grundy, F. J. \& Henkin, T. M The rpsD gene, encoding ribosomal protein S4, is autogenously regulated in Bacillus subtilis. J. Bacteriol. 173, 4595-4602 (1991).

8 Forsyth, R. A. et al. A genome-wide strategy for the identification of essential genes in Staphylococcus aureus. Mol. Microbiol. 43, 1387-1400 (2002).

9 Young, K. et al. Discovery of FabH/FabF inhibitors from natural products. Antimicrob. Agents Chemother. 50, 519-526 (2006).

10 Singh, S. B., Phillips, J. W. \& Wang, J. Highly sensitive target based whole cell antibacterial discovery strategy by antisense RNA silencing. Curr. Opin. Drug Discov. Devel. 10, 160-166 (2007).

11 Wang, J. et al. Platensimycin is a selective FabF inhibitor with potent antibiotic properties. Nature 441, 358-361 (2006)

12 Wang, J. et al. Platencin is a dual fabf and fabh inhibitor with potent in vivo antibiotic properties. Proc. Natl Acad. Sci. USA 104, 7612-7616 (2007).

13 Singh, S. B. et al. Isolation, structure, and absolute stereochemistry of platensimycin, a broad spectrum antibiotic discovered using an antisense differential sensitivity strategy. J. Am. Chem. Soc. 128, 11916-11920 and 15547 (2006).

14 Jayasuriya, H. et al. Isolation and structure of platencin: a novel FabH and FabF dual inhibitor with potent broad spectrum antibiotic activity produced by Streptomyces platensis MA7339. Angew. Chem. Int. Ed. 46, 4684-4688 (2007). 
15 Singh, S. B. et al. Discovery of lucensimycins A and B from Streptomyces lucensis MA7349 using an antisense strategy. Org. Lett. 8, 5449-5452 (2006).

16 Ondeyka, J. G. et al. Coniothyrione, a chlorocyclopentandienylbenzopyrone as a bacterial protein synthesis inhibitor discovered by antisense technology. J. Nat. Prod. 70, 668-670 (2007).

17 Zhang, C. et al. Isolation, structure and antibacterial activity of pleosporone from a pleosporalean ascomycete discovered by using antisense strategy. Bioorg. Med. Chem. (2008); e-pub ahead of print 12 April 2008; doi:10:1016/j.bmc.2008.04.18.

18 Zhang, C. et al. Isolation, structure and antibacterial activity of phaeosphenone from a Phaeosphaeria sp. discovered by antisense strategy. J. Nat. Prod. 71, 1304-1307 (2008).

19 Imai, H. et al. Okilactomycin, a novel antibiotic produced by a Streptomyces species. II. Structure determination. J. Antibiot. (Tokyo) 40, 1483-1489 (1987).

20 Smith, A. B. III, Basu, K. \& Bosanac, T. Total synthesis of (-)-okilactomycin. J. Am. Chem. Soc. 129, 14872-14874 (2007).
21 Imai, H. et al. Okilactomycin, a novel antibiotic produced by a Streptomyces species. I. Taxonomy, fermentation, isolation and characterization. J. Antibiot. (Tokyo) 40, 1475-1482 (1987).

22 Weisburg, W. G., Barns, S. M., Pelletier, D. A. \& Lane, D. J. 16S ribosomal DNA amplification for phylogenetic study. J. Bacteriol. 173, 697-703 (1991).

23 Lane, D. J. 16S/23S rRNA Sequencing, in Nucleic Acid Techniques in Bacterial Systematics (eds Stackebrandt, E. \& Goodfellow, M.) 115-175 (Wiley, New York, 1991).

24 Saitou, N. \& Nei, M. The neighbor-joining method: a new method for reconstructing phylogenetic trees. Mol. Biol. Evol. 4, 406-425 (1987).

25 Jukes, T. H. \& Cantor, C. Evolution of Protein Molecules, in Mammalian Protein Metabolism 21-132 (Academic Press, New York, 1969).

26 Kodali, S. et al. Determination of selectivity and efficacy of fatty acid synthesis inhibitors. J. Biol. Chem. 280, 1669-1677 (2005)

27 Onishi, H. R. et al. Antibacterial agents that inhibit lipid A biosynthesis. Science 274, 980-982 (1996). 